NBER WORKING PAPER SERIES

\title{
SEX, DRUGS, AND CATHOLIC SCHOOLS: PRIVATE SCHOOLING AND NON-MARKET ADOLESCENT BEHAVIORS
}

\author{
David Figlio \\ Jens Ludwig \\ Working Paper 7990 \\ http://www.nber.org/papers/w7990 \\ NATIONAL BUREAU OF ECONOMIC RESEARCH \\ 1050 Massachusetts Avenue \\ Cambridge, MA 02138 \\ November 2000
}

Thanks to Kevin Donohue and Justin Treloar for excellent research assistance, and to Charlie Brown, Dan Goldhaber, Jonathan Gruber, Helen Ladd, Derek Neal, Rosalie Pacula, Steve Pischke, Chris Ruhm, Lara Shore-Shepard, Patrick Wolf and seminar participants at the Association for Public Policy Analysis and Management and the National Bureau of Economic Research Children's Program for helpful comments. Thanks to the National Science Foundation and the American Education Research Association for financial support. Any errors and all opinions are our own.

(C) 2000 by David Figlio and Jens Ludwig. All rights reserved. Short sections of text, not to exceed two paragraphs, may be quoted without explicit permission provided that full credit, including $(\subset$ notice, is given to the source. 
Sex, Drugs, and Catholic Schools: Private Schooling

and Non-Market Adolescent Behaviors

David Figlio and Jens Ludwig

NBER Working Paper No. 7990

November 2000

JEL No. I2

\section{ABSTRACT}

This paper examines the effects of private schooling on adolescent non-market behaviors. We control for differences between private and public school students by making use of the rich set of covariates available with our NELS micro-dataset. We also employ an instrumental-variables strategy that exploits variation across metropolitan areas in the costs that parents face in transporting their children to private schools, which stem from differences in the quality of the local transportation infrastructure. We find evidence to suggest that religious private schooling reduces teen sexual activity, arrests, and use of hard drugs (cocaine), but not drinking, smoking, gang involvement, or marijuana use.

David Figlio

Department of Economics

University of Florida

Gainesville, FL 32611-7140

and NBER

figliodn@dale.cba.ufl.edu
Jens Ludwig

Georgetown University

3600 N Street, NW, Suite 200

Washington, DC 20007

ludwigj@gunet.georgetown.edu 


\section{INTRODUCTION}

Improving the quality of public schools is consistently among the American public's top priorities, ${ }^{1}$ a concern that is motivated by the growing importance of education for individual economic success (Levy and Murnane, 1992, Murnane, Willet and Levy, 1995, Murnane et al., 2000) as well as the considerable resources devoted to public education each year - around 4 percent of gross domestic product (U.S. Government Accounting Office, 1995). Widespread dissatisfaction with the performance of the public schools has generated growing interest in the possibility of privatizing the provision of elementary and secondary schooling, which in turn has led to debates about whether private schools are on average more effective than public schools.

To date, research has focused almost exclusively on public-private differences in academic outcomes. The best available evidence seems to suggest that existing private schools may on average produce slightly higher test scores and high school completion rates than public schools as currently constituted, at least among certain subgroups (Evans and Schwab, 1996; Figlio and Stone, 1999; Goldhaber, 1996; Ludwig, 1997; Neal, 1997; Rouse, 1998; Altonji, Elder and Taber, 2000).

Yet academic achievement is only one "output" from the educational process, and in fact many parents reportedly send their children to private schools largely to improve social rather than academic outcomes. Many policymakers also apparently believe that private schools are more effective in socializing students, as evidenced by suggestions that public schools adopt many of the practices used by private schools. For example, an influential member of the House

\footnotetext{
${ }^{1}$ For example, a USA Today / CNN / Gallup poll of 1,000 adults conducted from January 5 to 7, 1996 found that 67 percent of respondents listed the quality of public education as an issue that they would give "high priority" in deciding who to vote for; the second most frequently mentioned concern (by 66 percent of respondents) was violent crime (USA Today, "Ideal citizens go face to face," Richard Wolf, January 22, 1996, p. 6D).
} 
Judiciary Subcommittee on Crime has argued that public schools should display the Ten Commandments to reduce school shootings and other forms of delinquency, ${ }^{2}$ while the 2000 presidential race included a focus by some candidates on "effective character education" within the public schools. ${ }^{3}$ Yet despite the substantial interest in the effects of private schools on nonmarket behaviors, almost no systematic evidence is currently available on this point. ${ }^{4}$

The present paper examines the effects of private religious schooling on adolescent nonmarket outcomes using micro-data from the National Education Longitudinal Survey (NELS) of 1988, a longitudinal youth survey that focuses on education issues but also includes information about risky teen behaviors. We restrict our attention to religious schools because they constitute the large majority of all private schools in the U.S., and public subsidies to such schools are at the heart of most debates about school choice. The non-market behaviors of interest in our analysis include arrests, gang involvement, sexual activity and teenage fecundity, and the use of controlled substances such as tobacco, alcohol, marijuana and cocaine. Each of these behaviors impose substantial costs on society, and may also depress long-term labor-market and health

${ }^{2}$ Frank Bruni, "House Democrats Push Stricter Gun Rules," The New York Times, Friday, May 28, 1999, p. A17.

${ }^{3}$ Frank Bruni, "Bush Emphasizes Morals in Prescription for Education," The New York Times, Wednesday, November 3, 1999, p. A21, and "Full Text of Bush's Campaign Speech on Education," downloaded from www.nytimes.com/library/politics/camp/110399wh-gop-bushtext.html on February 8, 2000.

${ }^{4}$ Two previous studies that have examined private school effects on non-market outcomes using data for selected samples of adults. Greene, Giammo and Mellow (1999) use data from a national survey of Latino adults to examine the effects of prior private school attendance on political activity and tolerance. Wolf, Greene, Kleitz and Thalhammer (2000) examine the difference in civic values and political tolerance between private and public college students in a sample drawn from four colleges in Texas. 
outcomes for the teens themselves. ${ }^{5}$

The central challenge in estimating the effects of private schools is to control for unmeasured variables that may be correlated with both student behavior and the family's choice of school sector. The direction of bias introduced by such variables is difficult to predict. On the one hand, parents who are unusually engaged with their children's education may be more likely to pay the additional out-of-pocket expenses required for private schooling, in which case unmeasured family variables may lead to upward bias in positive outcomes (or downward bias in terms of delinquency measures). On the other hand, parents may be more likely to move disruptive children to private schools, in which case unobservables produce the opposite bias.

We address the selection-bias problem in two ways. First, the NELS micro-data used in our analysis provides unusually detailed information about individual students, families and schools. Important family-background variables are reported directly by the parents rather than taken from student reports, an important advantage over many of the other datasets that have

${ }^{5}$ Our motivation for studying adolescent criminal behavior stems from the enormous costs that crime imposes on American society - estimated to be on the order of $\$ 1$ trillion per year (Anderson, 1999). Interest in teen use of drugs and alcohol is motivated in part by evidence of a strong correlation with adult consumption, due in part perhaps to habit formation (Gruber, 2000, Gruber and Koszegi, 2000, Moore and Cook, 1995). Smoking has negative effects on health and imposes external costs on the rest of society (Manning et al., 1991), while heavy drinking elevates the risk of fatal motor vehicle accidents and interpersonal violence (Markowitz and Grossman, 1996, Cook and Moore, 1999, Levitt and Porter, 1999). Chronic marijuana use elevates the risk of cancer and bronchitis (Leuchtenberger, 1983, Caplan and Brigham, 1989, Tashkin et al., 1987, Newcombe and Bentler, 1988), impairs cognition and learning (Pope and Yurgelun-Todd, 1996), and may serve as a "gateway" to the use of more dangerous and addictive substances such as cocaine and heroin (Pacula, 1998). Unprotected sex may lead to sexually transmitted diseases (including, in rare cases, Human Immunodeficiency Virus infection); unwanted pregnancy may also result, which in turn may depress schooling outcomes and reduce labor supply and earnings, at least in the short term (Geronimus and Korenman, 1992, Hotz, McElroy and Sanders, 1999, Klepinger, Lundberg and Plotnick, 1999). 
been used to study private-school effects. Our rich set of controls for student and family backgrounds, including detailed measures of student substance use, misbehavior and sexual activity in the past, should help narrow the scope of omitted-variables problems.

Second, we use instrumental-variables (IV) methods to directly control for the possibility of unmeasured variables. Our instruments exploit variation across metropolitan areas in the effective price that parents face in transporting their children to private rather than public schools. While most public schools provide some assistance with transportation, in many areas the parents of private-school students are responsible for getting their children to and from school. Our identification strategy exploits the fact that metropolitan areas vary substantially with respect to the quality of the local public transportation infrastructure, and in particular the quality of the subway and other rail systems. Our instruments consist of interactions between measures of the local railway infrastructure and indicators of family socio-economic status (SES), which are negatively correlated with a household's demand for public transportation. The identification approach thus exploits the fact that the difference in private-school attendance rates between high- and low-SES families should be more modest in areas with high-quality public transportation. Yet it seems unlikely that the difference in risky behavior between high- and lowSES families should vary systematically with local transportation characteristics after conditioning on the school sector of attendance.

We find evidence to suggest that private religious schools reduce teen involvement in sexual activity, arrests, and use of hard drugs (cocaine). On the other hand, we find no evidence for private school effects on the use of other substances (alcohol, tobacco, or marijuana). We also find evidence of a process of "negative selection," in which parents whose teens are at 
highest risk for problem behaviors are more likely to send them to private religious schools. Unlike previous studies of academic outcomes, which find that private school effects are concentrated primarily among urban students (Neal, 1997, Grogger and Neal, 2000), the effects of religious private schools on non-academic outcomes are found primarily with suburban students and those residing in a household with two parents or guardians. Since our outcome variables come from student self-reports, there remains the possibility that these findings simply reflect differences in the propensity of students to report illegal or sensitive behaviors. Yet when we re-estimate our findings using only those students who appeared to report truthfully about their high school grades (determined by comparing self-reported grades with high school transcript data), our results are qualitatively similar.

The remainder of the paper is organized as follows. The next section discusses previous evidence on differences across school sectors that may be relevant for non-market behaviors. The third section discusses the NELS data, the fourth reviews our empirical strategy, the fifth section presents our empirical findings, and the sixth section concludes.

\section{SOCIALIZATION AND DISCIPLINE ACROSS SCHOOL SECTORS}

The belief that religious private schools may be more effective than public schools in socializing students stems in part from documented differences in school practices. Coleman, Hoffer and Kilgore (1982) report that the proportion of students in Catholic schools who report that their school is "excellent" or "good" in effectiveness of discipline is substantially higher than what is reported by public school students (72 versus 42 percent); similar differences are observed in student reports of the fairness of discipline (46 versus 36 percent). Enhanced supervision and discipline may deter misbehavior at school by increasing the probability of 
punishment for infractions on school grounds, and in fact the proportion of students and administrators who report student-behavior problems in the schools is far lower in the private than public sector (Coleman, Hoffer and Kilgore, 1982; Bryk, Lee and Holland, 1993). Changes in behavior at school could spill over to non-school hours if misbehavior is habituating, or if there are complementarities in the production of in- and out-of-school misbehavior. ${ }^{6}$

A very different mechanism is suggested by the possibility that students may compete for prestige by acting rebellious. ${ }^{7}$ Catholic schools not only have more effective discipline, but many also have regulations regarding such mundane matters as the student's manner of dress. Strict rules about trivial behaviors may enable students to signal that they are rebellious at the cost of relatively minor infractions of school rules. In contrast, students who wish to identify themselves as "misbehavers" in public schools must resort to more serious activities than wearing white socks with their dark pants and dress shoes.

While there has been a change in recent years in the way that Catholic schools provide religious instruction, such as an increase in the proportion of religion classes taught by lay faculty, such courses nevertheless remain an important part of the curriculum in most Catholic schools (Bryk, Lee and Holland, 1993). Such instruction could affect student's "tastes" for

${ }^{6}$ For example, some out-of-school fights may be in retaliation for earlier arguments or fights that occurred at school. It is also possible that schools are an important distribution center for acquiring illegal drugs or weapons.

${ }^{7}$ This is similar to the argument that many goods are allocated through non-market mechanisms, and as a result prestige and relative standing may matter to individuals (Cole, Mailath and Postlewaite, 1992). The same argument may apply to the behavior of high school students - most delinquency (at least serious delinquency) is committed by boys, and for those who are not star athletes, misbehavior may be a viable way to compete for non-market "goods" (in this case, girls). 
misbehavior, or increase the perceived costs of misbehavior by defining a number of activities as sins that have eternal consequences.

Students in Catholic schools also spend more time on homework and extracurricular activities than those in public schools (Coleman, Hoffer and Kilgore, 1982; Figlio and Stone, 1999). Private schools may thus reduce delinquency if only because of an "incapacitation effect" - teens who are doing homework or running track are not out looking for trouble.

Finally, private schools may indirectly reduce teen problem behavior by exposing them to more pro-social peer groups, or by improving students' academic achievement. The first possibility is suggested by the fact that private schools have a greater ability than public schools to select and expel students, and may thus be less susceptible to "epidemics" of problem behaviors. $^{8}$ Private schools may also increase the opportunity costs of engaging in problem behaviors by improving academic achievement and consequently future labor market outcomes (Freeman, 1995, Murnane et al., 2000).

\section{DATA}

We begin by discussing the NELS data, and then review our delinquency measures and control variables.

\section{A. NELS}

The National Education Longitudinal Study of 1988 (NELS), sponsored by the U.S.

${ }^{8}$ The potential importance of peer effects is highlighted by a recent evaluation of a randomized housing-mobility experiment, which finds that moving teens from high- to lowpoverty neighborhoods produces substantial reductions in violent offending and other teen problem behaviors (Katz, Kling and Liebman, 2000; Ludwig, Duncan and Hirschfield, forthcoming). For other evidence on the effects of peer groups see Borjas (1995). For a review of the literature on "social contagion" see Cook and Goss (1996). 
Department of Education, surveyed a nationally-representative sample of eighth-grade students in 1988, with follow-up interviews in 1990 and 1992. The original sample employed a two-stage sampling design, with 1,052 schools selected in the first stage and 26 students per school selected in the second. ${ }^{9}$ In our single-equation estimates we calculate Huber-White standard errors to adjust for the clustering of students in schools; as discussed below, since our instruments vary at the level of the metropolitan area a slightly different adjustment is required for our IV estimates.

Base year participants were selected to participate in follow-up surveys in part on the basis of the number of other base-year NELS participants in the student's school at the time; dropouts were also retained in the sampling frame (U.S. Department of Education, 1994).$^{10}$ Our final sample size is approximately 10,500 (this number varies a bit by dependent variable) out of the 27,805 initial observations in the NELS. A total of 10,412 observations are lost because the students are not surveyed in follow-up waves; most of these students are not interviewed because they were not included in the NELS follow-up sampling frame. We intentionally exclude the 4,982 students who live outside of metropolitan areas in 1990 (for whom we cannot construct our instruments), as well as the 802 students who are in non-religious private schools during the first follow-up. We lose 226 of the remaining observations because we are missing our instrumental

${ }^{9}$ Excluded from the NELS sample in 1988 were students with mental handicaps, physical or emotional problems, and inadequate command of the English language. In most cases, 24 of the 26 students per school included in NELS were randomly sampled, while the other two students were selected from among the Hispanic and Asian Islander students (U.S. Department of Education, 1994).

${ }^{10}$ While follow-up achievement test data is missing for a large proportion of students who have dropped out due to the heavy reliance on telephone surveying for this population (U.S. Department of Education, 1994, Grogger and Neal, 2000), this will have no effect on our analysis because all of our outcome measures come from the survey questionnaires. 
variables (because we observe our instruments for most, but not all, metropolitan areas.) The remaining observation losses are due to a missing dependent variable or covariate.

The Department of Education provides weighting variables that account for the probability of participation in the base-year and follow-up surveys, as well as school administrator and student survey non-response (U.S. Department of Education, 1994). Our descriptive tabulations are all calculated using these weights. While our preferred multivariate regression results are run without these weights (in order to improve the efficiency of our estimates), as shown below, the point estimates from the weighted and unweighted IV analyses tell a qualitatively similar story.

For our purposes, the NELS data offer at least five advantages over previous youth surveys: a large sample; data on key aspects of family's socioeconomic status taken from parent (rather than teen) surveys; data on school and student-body characteristics taken from school administrators; the measurement of teen non-market outcomes at multiple points in time, which enables us to condition on previous misbehavior; and the retention of dropouts in the sampling frame. We pool information from the student and dropout data to calculate all of our estimates.

\section{B. Delinquency Measures}

Our empirical analysis focuses on several different dichotomous dependent variables designed to measure whether the respondent was involved in a particular delinquent behavior measured at the time of the second follow-up survey in 1992, when most respondents were around age 18. These variables are derived from NELS participant responses to selfadministered pencil-and-paper questionnaires (U.S. Department of Education, 1994). While selfadministered questionnaires seem to yield somewhat lower estimates for the prevalence of 
sensitive behaviors than computer-assisted methods (Turner et al., 1998), as shown below it does not appear that misreporting substantially distorts our findings.

The first dependent variable of interest measures involvement with the criminal justice system, equal to 1 if respondent reported having been arrested during the previous academic term (or their last term in school for dropouts) during the second follow-up. The arrest rates reported by NELS teens are quite similar to those implied by national arrest data. ${ }^{11}$ Our other measure of criminal or delinquent behavior is equal to 1 if the respondent reports belonging to a gang at the time of the 1992 interview. Around 3 percent of NELS respondents report gang membership in 1992, which is fairly consistent with other national estimates. ${ }^{12}$

Our second set of outcome variables measure the use of controlled substances. We create four dichotomous indicators equal to 1 if the respondent reports that she smokes at least occasionally at the time of the 1992 survey, or has had alcohol, used marijuana, or used cocaine during the last 12 months. Rates of self-reported drug use in the NELS are quite consistent with

${ }^{11}$ For example, in the first NELS follow-up in 1990 (when most students were 15 or 16), 6 percent of male students had been arrested during the previous term. By comparison, data from the Federal Bureau of Investigation's Uniform Crime Report system suggest that 10 percent of teens age 15 and 12 percent of teens age 16 were arrested during 1990 (FBI, 1991). Since the NELS question covers half a school year, and a fair proportion of juvenile criminal activity may occur over the summer, the NELS results seem reasonable.

${ }^{12}$ Klein (1995) estimates that there were a total of 9,000 street gangs with 400,000 members in the U.S. in 1992. By way of comparison, there were around 24 million teenagers (ages 13 to 19) in the U.S. in 1992 (U.S. Bureau of the Census, 1994; if we assume that gang membership is restricted to teenagers, this implies a gang membership rate of nearly 2 percent. The discrepancy between the NELS and the Klein estimates could be explained if the rate of gang membership is somewhat higher for older than younger teenagers, or because Klein uses a very specific definition of gangs that excludes among other things "generally non-violent cohorts such as stoners, tagger crews, and 'normal' adolescent peer groups that do on occasion get themselves into illegal patterns of activity" (Klein, 1995, p. 218). 
those reported in other surveys of American adolescents. ${ }^{13}$

Finally, we use questions from the third NELS follow-up to measure whether the teen had sex before 1992, and whether the teen had fathered or mothered a child before $1992 .{ }^{14}$

\section{Control Variables}

Descriptive statistics for selected control variables are presented in Table 1. Our empirical models control for a standard set of family background characteristics obtained from parent self-reports, including mother's and father's educational attainment and family income (all coded as a set of dummy variables to allow for non-linear effects of socioeconomic status on teen behavior), whether the child's father or other adult male guardian is living in the home, the number of children in the family, urbanicity, region, foreign-language status, and a detailed set of indicators for the student's religious affiliation. ${ }^{15}$ We also control for a number of student outcomes from eighth grade, including whether the teen smoked or had sex, the frequency with which the teen skipped classes and missed school during the past four weeks, got into fights, or was sent to the office. We also control for the teens's performance on standardized reading,

${ }^{13}$ Data from NELS suggest lifetime prevalence for teens who should be in $10^{\text {th }}$ grade in 1990 of 23 and 4 percent for marijuana and cocaine use, identical to the results of the first Monitoring the Future survey of $10^{\text {th }}$ graders in 1991 (NIDA, 1996).

${ }^{14}$ The third follow-up survey is the first opportunity we have to observe these behaviors. Because of respondent attrition, sample sizes are therefore smaller for these outcomes than for the others. However, the evidence suggests that this is unlikely to bias our results: singleequation estimates for the other outcome variables are qualitatively similar whether or not we exclude those individuals for whom we are missing third follow-up data.

${ }^{15}$ We include a set of indicators for the following religious groups (Catholic is the omitted group): Baptist; other Protestant; Mormon; Eastern religion; Jewish; Moslem; and no religious affiliation. 
mathematics, science, and history achievement tests. ${ }^{16}$

We do not include controls for the student's "religiosity," which is typically measured as the frequency with which students attend religious services, because this behavior may itself be a direct outcome of attending religious schools. For example, some religious private schools offer religious services at the school during the school day, and some make attendance at such services mandatory. We also do not include controls for school resources. While we are interested in both the relative effectiveness and efficiency of private versus public schools, measuring the true value of the inputs used by private and public schools is difficult, particularly with the resource variables available with the NELS. ${ }^{17}$

\section{EMPIRICAL STRATEGY}

Our dependent variables, $Y_{\mathrm{ij}}$, are dichotomous indicators for whether adolescent (i) living in metropolitan area $(j)$ has been engaged in a particular criminal or delinquent behavior. We are interested in obtaining consistent estimates for the parameter $\beta_{1}$ in equation (1), which represents the effects of attending a religious private school $\left(\mathrm{T}_{\mathrm{ij}}=1\right)$ on the outcomes of interest. (This setup can be motivated in the standard way, by assuming $Y_{\mathrm{ij}}$ is an indicator for an underlying continuous latent variable within a utility-maximizing framework). The key concern is that since

${ }^{16} \mathrm{We}$ also include missing-data flags for these variables.

${ }^{17}$ Measuring the relative efficiency across school sectors is complicated in part by the fact that the NELS only provides measures that approximate per-pupil instructional expenditures (such as pupil-teacher ratios and teacher salaries). If private schools devote a larger share of their operating budgets to instructional items, then controlling for instructional spending will understate the relative efficiency of private schools. Another complication is that even total perpupil expenditures may provide a misleading picture of relative expenditures across school sectors, since many Catholic schools may receive in-kind subsidies from affiliated religious organizations and employees that are not included in traditional school-spending calculations. 
families choose whether to attend private schools, and in fact incur non-trivial marginal costs to opt out of the public school system, school sector may be correlated with unobserved student- or family-level characteristics (equation 2). In this case, estimates of $\beta_{1}$ from a standard probit, logit, or linear probability model may be biased.

$$
\begin{aligned}
& Y_{i j}=\beta_{0}+\beta_{1} T_{i j}+\beta_{2} X_{i j}+\mu_{i j} \\
& E\left[T_{i j} \mu_{i j}\right] \neq 0
\end{aligned}
$$

We address this endogeneity problem by using an instrumental-variables strategy that uses variation across areas in the non-tuition price of attending private schools due to differences in transportation costs. ${ }^{18}$ While most jurisdictions provide or subsidize the transport of children to public schools, only 11 states subsidize the transportation of students to private schools (Gold, Smith and Lawton, 1995). The costs to parents of transporting their children to school in terms of both time and money should thus be a relevant factor in deciding between school sectors.

We exploit the fact that there is variation across metropolitan statistical areas (MSA's) in the quality of the local transportation infrastructure, which will in turn affect the costs to parents of choosing private rather than public schools. Specifically, we exploit variation across MSA's in the quality of the local railway transportation infrastructure, as measured by the number of railcars per capita in the local public transportation system taken from the Places Rated Almanac

${ }^{18}$ A number of studies have used students' religious affiliations to identify the effects of private schooling on academic outcomes, motivated by the observation that Catholic students are more likely than others to attend private (particularly Catholic) schools. Yet there is some evidence to suggest that religion may be correlated with unobserved family attributes that are relevant for academic achievement (Murnane, Newstead and Olsen, 1985, Neal, 1997, Ludwig, 1997, Figlio and Stone, 1999), and also appears to be correlated with non-market adolescents behaviors, as we demonstrate below. Another possibility is to focus on variation across areas in the tuition price of attending private schools, although as Altonji, Elder and Taber (2000) argue, tuition levels are likely to be correlated with the effectiveness of local private schools. 
(PRA). The PRA provides data on public transportation services for each of the Censusdesignated Standard MSA's in the U.S. as of 1990, which together capture 62 percent of the NELS sample given their 1990 (first follow-up) residential addresses. ${ }^{19}$ We exclude from our analytic sample the rural NELS participants who live outside of metropolitan areas. Twenty two of the 182 MSA's have railway systems, which together account for one-third of the NELS students living within MSA's. There is also considerable variation in the number of railcars per 100,000 MSA residents within those areas that have railway systems, ranging from 0.23 to a high of 35.04 .

Our identification strategy also exploits the fact that there is variation in the demand for public transportation across socio-economic strata. On average people seem to value time traveling in a vehicle at 40 to 50 percent of their hourly wage, and value travel time outside of a vehicle at around 130 percent of their wage rate (Small and Winston, 1999). Because travel time is thus more costly for higher-wage adults, and private automobiles typically offer lower travel times than public transportation (particularly for out-of-vehicle time), SES is positively correlated with automobile use and negatively correlated with demand for public transportation. The implication is that a metropolitan area's public transportation infrastructure should have a greater effect on the non-tuition costs of private schooling for the lower-SES families who rely on public transportation the most.

The identification approach can be illustrated by some descriptive calculations using data

${ }^{19}$ We identify the MSAs in which NELS students live on the basis of the geographic location of each student's school. We are able to identify the geographic location of private and public schools in the NELS using a matching crosswalk developed by Figlio and Stone (1999) based on proprietary data purchased from Dun and Bradstreet, as well as telephone conversations with private schools themselves. 
from the 1990 Census for Miami, Florida. We observe that, conditioning on the income and racial distribution of the Census tract, residents of Census tracts located within one mile of a Miami Metrorail station were over 30 percent more likely to send their school-aged children to private school than were residents of Census tracts located between one and three miles from a Metrorail station, and over 40 percent more likely than residents of Census tracts located more than three miles away. Furthermore, this relationship is more pronounced among Census tracts that are disproportionately low-SES or minority-populated..$^{20}$ The accessibility of public transportation seems to affect decisions about whether to send children to private rather than public schools, particularly for poor and minority families.

The set of instruments used in our analysis thus includes (in addition to railcars per capita) a series of interactions between the railcar variable and categorical indicators for mother's education and family income. The intuition behind these instruments is that the difference between high- and low-SES families in the probability of attending private schools should be smaller in MSA's with high-quality public transportation systems. Yet there is little reason to believe that the difference between high- and low-SES families in the propensity of teens to engage in risky or anti-social behaviors should vary systematically with the quality of the local railway system after conditioning on the school sector of attendance.

We use these instruments $\left(Z_{1 \mathrm{ij}}\right)$ to estimate the system of equations in (3) and (4) using two-stage least squares (2SLS). One complication comes from the fact that our instruments vary at the level of the metropolitan area rather than the individual, which in turn will lead to downward bias in the standard errors for the second-stage point estimates. We address this

\footnotetext{
${ }^{20}$ Details on this analysis are available on request from the authors.
} 
problem by estimating Huber-White standard errors in the second stage using the formula shown in equation (5) from Shore-Sheppard (1996), where $\mathrm{e}_{\mathrm{ij}}$ represents the residuals from the secondstage IV regression and $\mathrm{Z}$ is the matrix representation of $\left[\mathrm{X}_{\mathrm{ij}} \mathrm{Z}_{1 \mathrm{ij}}\right]$.

$$
\begin{aligned}
& \mathrm{C}_{\mathrm{ij}}=\alpha_{0}+\alpha_{1} \mathrm{X}_{\mathrm{ij}}+\alpha_{2} \mathrm{Z}_{1 \mathrm{ij}}+v_{\mathrm{ij}} \\
& \mathrm{Y}_{\mathrm{ij}}=\beta_{0}+\beta_{1} \mathrm{C}_{\mathrm{ij}}+\beta_{2} \mathrm{X}_{\mathrm{ij}}+\epsilon_{\mathrm{ij}} \\
& \operatorname{Var}[\beta]=\left[\mathrm{X}^{\prime} \mathrm{Z}\left(\mathrm{Z}^{\prime} \mathrm{Z}\right)^{-1} Z^{\prime} \mathrm{X}\right]^{-1} \mathrm{~V}\left[\mathrm{X}^{\prime} Z\left(Z^{\prime} Z\right)^{-1} Z^{\prime} \mathrm{X}\right] \\
& \text { where } \mathrm{V}=\sum_{\mathrm{j}}\left[\sum_{\mathrm{i}} \mathrm{u}_{\mathrm{ij}}{ }^{\prime} \mathrm{u}_{\mathrm{ij}}\right] \text { and } \mathrm{u}_{\mathrm{ij}}{ }^{\prime}=\mathrm{e}_{\mathrm{ij}}\left(\mathrm{X}^{\prime} Z\right)\left(Z^{\prime} Z\right)^{-1} Z_{\mathrm{ij}}{ }^{\prime}
\end{aligned}
$$

The variation of our instruments at the level of the MSA rather than student also complicates our efforts to test the assumption that the instruments are orthogonal to the secondstage regression residuals. We test this assumption using the generalized method of moments (GMM) over-identification test from Hoxby and Paserman (1998). The GMM overidentification test statistic is calculated as in equation (6), distributed as a chi-squared with degrees of freedom equal to the number of exclusion restrictions, where e represents the vector of IV residuals $\mathrm{e}_{\mathrm{ij}}$ and $\mathrm{Z}_{1}$ is the matrix version of $\mathrm{z}_{1 \mathrm{ij} \cdot}{ }^{21}$

$$
\begin{aligned}
& \mathrm{Ng}^{\prime} \mathrm{W}^{-1} \mathrm{~g} \rightarrow \chi^{2}(\mathrm{k}) \\
& \text { where } \mathrm{W}=(1 / \mathrm{N}) \sum_{\mathrm{j}}\left[\left(\sum_{\mathrm{i}} \mathrm{z}_{\mathrm{lij}} \mathrm{e}_{\mathrm{ij}}\right)\left(\sum_{\mathrm{i}} \mathrm{e}_{\mathrm{ij}} \mathrm{z}_{\mathrm{lij}}{ }^{\prime}\right)\right] \text { and } \mathrm{g}=\mathrm{Z}_{1}{ }^{\prime} \mathrm{e}
\end{aligned}
$$

\section{EMPIRICAL RESULTS}

In this section we present descriptive results from our data and the key IV estimates for

${ }^{21}$ When observations within MSAs are correlated, the GMM over-identification test from equation (6) produces smaller test statistics than the standard over-identification test described by Hausman (1983) and Newey (1985), in which the second-stage IV residuals are regressed directly against the instruments. In our application the GMM test statistics are typically one-third to twothirds as large as the standard over-identification test statistics, although in almost every case even the standard over-identification test fails to reject the null hypothesis. 
the effects of religious private schooling on adolescent non-market outcomes. We then demonstrate that our findings are robust to a number of different modeling assumptions, and conclude by examining the effects on different sub-groups of students.

\section{A. Descriptive Results}

Table 1 presents descriptive statistics for the full sample of students who participated in the 1988 through 1992 waves of NELS, calculated using the second follow-up weights. Around 90 percent of all students in the sample attended public schools in 1990; another 8 percent or so attended private religious schools, most of which are Catholic, and another 2 percent attend nonreligious private schools. We focus on the public and religious private schools.

Table 2 shows that drinking and sexual activity is remarkably common among American 18-year-olds, as is smoking both tobacco and marijuana. While teen parenthood, arrests, gang membership and cocaine use are less common, it is still the case that a non-trivial share of students engage in these risky behaviors.

The unadjusted differences in the prevalence of these behaviors across school sectors are quite substantial for sexual activity, fecundity, and arrests. On the other hand, students in public and religious private schools engage in other risky behaviors at approximately the same rate. Table 2 also shows that the prevalence of risky behaviors for the full sample of students who participate in the 1988 through 1992 waves (top panel) is similar to what is observed among the MSA sample used in our analysis.

The differences across school sectors in sexual activity, fecundity and arrests generally persist even after we control for detailed family background characteristics, although the 
magnitudes of these differences are reduced by 50 to 75 percent (Table 3). ${ }^{22}$ We also find that the linear probability model's treatment effects are typically quite similar to the marginal effects implied by the probit regression coefficients. This result is important because it suggests that our instrumental variables models, in which we use a linear 2SLS approach, are not likely to be driven by this choice of model specification. ${ }^{23}$ As Grogger and Neal (2000) note, the use of the NELS sampling weights produce slightly larger private-public differences with single-equation methods.

The other relevant finding from the single-equation results summarized in Table 3 concerns the statistically significant effect of student religious affiliation on a number of nonmarket behaviors, even after we have controlled for a detailed set of family background characteristics and $8^{\text {th }}$ grade student behaviors. For example, Catholic teens are more likely to drink and have had sex by 1992 than those in other religious groups. The lesson is that while a number of studies have used measures of religious affiliation as instrumental variables in studying the effects of private schools on academic outcomes, religion does not appear to be a valid instrument in our application. ${ }^{24}$

\section{B. Instrumental Variables Estimates}

Our instruments have fairly strong explanatory power in the first-stage model for the

${ }^{22}$ These estimates and those that follow are calculated without the NELS sampling weights; a subsequent section discusses the effects of the sampling weights on our estimates.

${ }^{23}$ This is unsurprising, given that similar results were found previously by Evans and Schwab (1997) and Figlio and Stone (1999) in the context of academic performance differences between public and private schools.

${ }^{24} \mathrm{~F}$-tests reject the null hypothesis that the religion variables are jointly equal to zero in the single-equation estimates for sexual activity, fecundity, drinking, and marijuana use. 
decision to attend private religious rather than public schools. For example, Table 4 presents the first-stage coefficients for the instrumental variables using the sample of NELS teens for whom data on sexual activity by 1992 is available. The F-statistic for the joint significance of the instruments is equal to $12.75(\mathrm{p}<.001)$, which exceeds the cutoff value of 10 suggested by Staiger and Stock (1997).

Table 4 also shows that, as expected, increases in the number of railcars per capita within a MSA increases the probability of private-school attendance for children whose families have low or moderate incomes, and for children whose mothers have lower levels of educational attainment. We also find that improvements in the railway system increase the probability of attending private schools for children for whom maternal education is missing, whom we believe have mothers who are disproportionately likely to have low or moderate levels of schooling. ${ }^{25}$

Children of very highly educated mothers appear to be if anything somewhat less likely to attend religious private school when the surrounding MSA has a high-quality railway system. It is possible that higher-SES families are in part opting out of religious private schools when these schools enroll proportionately more lower-SES families, a possibility that we control for by including peer measures in our sensitivity-test section below. When we do this, we observe that

${ }^{25}$ Some evidence that mothers with low or moderate levels of schooling appear to be less likely to respond to the NELS parent survey (or the parent-survey question about education in particular) comes from our single-equation estimates above. We find that the indicator for mother's-education-missing typically has a coefficient that is more similar in sign and magnitude to the coefficients for maternal education categories below college completion. We also find that in cases where mother's education is missing but family income data are available, 62 percent report family incomes below $\$ 35,000$ per year and fully 80 percent report annual incomes less than $\$ 50,000$. Furthermore, we find that students with missing maternal education report mother's expectations of how far in school the student will go at about the same rate of students with mothers observed not to have attended any college. 
our results do not change much, implying that this alternative explanation is not responsible for our findings. Likewise, it is possible that our instruments merely reflect the costs to parents of engaging with their child's school, but, as we report below, our results are virtually unchanged when we control for measures of parental involvement in the school. Another possible explanation is that high-SES families utilize public transportation to send their children to nonreligious private schools in metropolitan areas with well-developed railway systems. This possibility is suggested by the fact that "elite" private schools are disproportionately located in cities, while high-SES families disproportionately live in the suburbs.

When we use instrumental variables in an attempt to overcome the self-selection problem (Table 5), we find even larger effects of religious private schools on adolescent non-market behaviors than those produced by the single-equation estimates. These (unweighted) IV estimates suggests that students in private schools are 24 percentage points less likely to have had sex by 1992 than their public school counterparts, equal to around one-third the fraction of public school students who reported having had sex as of the NELS second follow-up (Table 2).

In fact, the effects of private schooling to depress fecundity, arrests, and cocaine use among teens is even larger than the prevalence of each of these behaviors among public school students (Table 2). Assuming that our instruments are orthogonal to the second-stage residuals, the IV procedure in this case identifies the effects of the private school "treatment" on those students who are induced to switch school sectors by variation in the instruments (Imbens and Angrist, 1994). Under this "local average treatment effect" (LATE) interpretation, those students with above-average rates of problem behaviors appear to be more likely to be sent to private schools by their parents when transportation costs are low, and also appear to derive substantial 
benefits from religious private school attendance.

Our findings thus suggest a process of "negative selection" in which children at greatest risk for problem behavior are provided by parents with the private school treatment. This pattern differs from the usual assumptions about "positive selection" into private schools, but is consistent with findings from the U.S. Department of Housing and Urban Development's Moving to Opportunity (MTO) residential-mobility experiment. Research on the Baltimore and Boston MTO sites suggests that parents whose children were at greatest risk of problem behavior during the post-program period are more likely to relocate to lower-poverty areas through the program (Katz, Kling and Liebman, 2000; Ludwig, Duncan and Hirschfield, forthcoming).

\section{Sensitivity Analyses}

While we prefer unweighted to weighted IV analysis for reasons of efficiency, Grogger and Neal (2000) argue in favor of weighting. As seen in Table 6, using the NELS sampling weights increases the magnitude (in absolute value) of both the point estimates and the standard errors for the estimated private-school effects on sexual activity, arrests, and cocaine use, while the effect on fecundity disappears. Weighting also suggests a positive effect of religious private schooling on marijuana use, although this estimate seems to be driven by the relatively small share of NELS participants who receive disproportionately large weights. ${ }^{26}$ When we set the weights for the bottom and top 5 percent of the sample equal to the $5^{\text {th }}$ and $95^{\text {th }}$ percentiles of the weight variable, respectively, the marijuana effect essentially disappears. In any case, the bottom line is that the estimated negative effects of religious private schooling on sexual activity, arrests

${ }^{26}$ For example, while the average value of the second follow-up questionnaire weight (f2qwt) is equal to 141.7 in our sample, 5 percent of the sample has a weight value greater than 353.8 and the top 1 percent have weights in excess of 793 . 
and cocaine use appear to be fairly robust to decisions about whether to use sampling weights.

Table 6 also shows that the IV estimates are robust to whether peer variables are included in the model, which in this case are equal to the proportion of other students in the school who are African-American, Hispanic, or eligible for free- or reduced-price lunch. This finding helps rule out the possibility, raised above, that a peer-attribute story is responsible for our IV results. In principle variation in the local transportation infrastructure could have a direct effect on teen outcomes by affecting the involvement of parents in their children's schooling, but Table 6 shows that the results are also robust to the inclusion of variables measuring the frequency with which parents attend PTA meetings and are involved in other ways with parent-teacher organizations. Relatedly, the results are quite similar when we use the railcars per capita variable itself as a control variable rather than as an instrument. It is also possible that the railway infrastructure variable simply serves as a proxy for MSA size, as railway infrastructure is more prevalent in larger MSAs, but the pattern of results is qualitatively similar when we include MSA population as a control variable.

One final concern with our findings is the possibility that students misreport on their involvement in risky or anti-social behaviors, and that the degree of misreporting may vary across school sectors. To examine the sensitivity of our results to this problem, we replicate our analyses after omitting the students who appear to have substantially misreported their math and English grades when questioned in the NELS survey. ${ }^{27}$ (Recall that we observe both student-

${ }^{27}$ Separately for both math and reading grades, we construct a measure of the discrepancy between the student's self-reported math (or reading) grades and those reported on the NELS transcript data file. We then drop those students who are in the top 5 percent of the distributions for over-stating either their reading or math grades. 
reported data and actual transcript data on grades for NELS students). The results are reported in Table 6, and are quite similar to those obtained using the full sample. Either there is little overlap in the set of students who misreport their grades versus those who misreport involvement in delinquent behaviors, or student misreporting does not substantially distort our findings. ${ }^{28}$

\section{Subgroup Analyses}

Previous research on the effects of private schooling on academic outcomes (Evans and Schwab, 1995; Neal, 1997; Figlio and Stone, 1999; Grogger and Neal, 2000) finds that private school treatment effects are heterogeneous across subgroups. While the present analysis focuses on a considerably different outcome than these previous papers, it is important to gauge the degree to which the results reported above vary across sub-groups. To this end, we report in Table 7 six sets of instrumental variables estimates for males, females, urban residents, suburban residents, students in single-parent households, and students in two-parent households. The results indicate that there exist considerable differences across groups in the effects of religious schooling. This section describes the principal differences.

We first note that there are substantial differences across the sexes in which outcomes appear to be affected by private religious schooling. Private religious schooling is estimated to reduce teenage sexual activity, as well as teenage fecundity, among girls, while these effects are not observed among boys (though both point estimates are negative.) On the other hand, religious private schooling reduces problem behaviors like arrests, smoking and cocaine use only

${ }^{28}$ Interestingly enough, single-equation estimates reveal no statistically significant differences between religious private and public school students in the probability of substantially misreporting math or reading grades, although our IV model shows a statistically significant difference of 10 percentage points (with religious private-school students less likely to misreport). 
among boys.

While previous studies find that private schools improve educational outcomes primarily for urban students (Neal, 1997, Grogger and Neal, 2000), our study finds that religious private schooling improves non-market outcomes primarily among suburban students. However, we note that only around one-quarter of our analytic sample is classified as urban under the NELS definition, so the standard errors around the second-stage IV estimates for urban students are fairly large.

Consistent with the finding that religious private schooling primarily affects the nonmarket behaviors of suburban teens, we also find that these effects are concentrated among teens who live in households with two parents or guardians (Table 7). Indeed, in no case do we find evidence of a statistically significant effect of religious private schools for single-parent households, although one effect (a negative effect on cocaine use) approaches statistical significance and has a point estimate larger than its (statistically significant) two-parent household counterpart.

\section{DISCUSSION}

It is often perceived that private schools are "better" than public schools in discouraging delinquent behavior. However, as this is the first study to explore the effects of private schooling on delinquency, to date this perception is merely speculation, rather than based on evidence.

Our analysis of data from the NELS finds that religious private schooling seems to produce substantial reductions in teen sexual activity, arrests, and the use of hard drugs (specifically cocaine). These estimates are generally robust to the choice of model specification or use of sampling weights. On the other hand, we do not find consistent evidence that religious 
private schooling affects teen drinking, marijuana use, gang involvement, or smoking. It is also interesting that our findings suggest a process of "negative selection," in which the parents of those teens at highest risk for involvement in sexual activity or problem behavior are more likely to send their children to religious private schools.

As with any IV analysis, there inevitably remains some question about whether our instruments are truly exogenous. Yet we produce generally similar findings when we identify our estimates using only the interaction terms between family SES and measures of the local area's public transportation infrastructure. Our use of a rich set of $8^{\text {th }}$ grade student behavioral outcomes and family background characteristics as controls also helps reduce the scope for omitted variables problems.

The ultimate implications for public policy are difficult to determine. Could public schools reduce teen sexual activity by either including "character education" as part of the curriculum without reference to specific religious ideologies, or dropping sex and drug education classes? More generally, are there other policies that public schools could adapt from religious private schools that would improve the academic or non-academic outcomes of students? These are important questions that our study cannot answer.

The implications for school choice programs are also unclear, since the effects of largescale choice efforts will depend in large part on the private-school supply response, the relative quality of new entrants into the educational market, the sorting outcomes that would result from large-scale programs with different design features, and the importance of peer effects for academic and non-academic youth outcomes. While some cautionary evidence on the effects of school choice is now available from New Zealand, which has adopted a national policy of school 
choice and independent school autonomy (Fiske and Ladd, 2000), more evidence on these points is required within the context of the American educational and political systems. 


\section{REFERENCES}

Altonji, Joseph, Todd Elder, and Christopher Taber (2000) "Selection on Observed and Unobserved Variables: Assessing the Effectiveness of Catholic Schools." Working Paper, Northwestern University.

Anderson, David A. (1999) “The Aggregate Burden of Crime." Journal of Law and Economics.

Borjas, George J. (1995) "Ethnicity, Neighborhoods, and Human-Capital Externalities." American Economic Review. 85(3): 365-390.

Bryk, Anthony S., Valerie E. Lee, and Peter B. Holland (1993) Catholic Schools and the Common Good. Cambridge, MA: Harvard University Press.

Caplan, GA and Brigham, BA (1989) "Marijuana Smoking and Carcinoma of the Tongue: Is There an Association?" Cancer. 66: 1005-6.

Cole, Harold L., George J. Mailath, and Andrew Postlewaite (1992) "Social Norms, Savings Behavior, and Growth.” Journal of Political Economy. 100(6): 1092-1125.

Coleman, James S., Thomas Hoffer, and Sally Kilgore. (1982) High School Achievement: Public, Catholic, and Private Schools Compared. New York: Basic Books.

Cook, Philip J. and Kristin Goss (1996) "A Selective Review of the Social-Contagion Literature.” Working Paper, Duke University.

Cook, Philip J. and Michael J. Moore (1999) “Alcohol.” NBER Working Paper No. W6905.

Evans, William N. and Robert M. Schwab. (1995) "Finishing School and Starting College: Do Catholic Schools Make A Difference?" Quarterly Journal of Economics. 110(4): 941-974.

Federal Bureau of Investigation (1991) Crime in the United States, 1990. Washington, DC: U.S. Government Printing Office.

Figlio, David N. and Joe A. Stone. (1999) “Are Private Schools Really Better?” Forthcoming, Research in Labor Economics.

Fiske, Edward B. and Helen F. Ladd (2000) When Schools Compete: A Cautionary Tale. Washington, DC: Brookings Institution.

Freeman, Richard B. (1995) “The Labor Market.” In Crime. James Q. Wilson and Joan Petersilia (Eds.) San Francisco, CA: Institute for Contemporary Studies Press. pp. 171-192. 
Geronimus, Arlene and Sanders Korenman (1992) "The Socioeconomic Consequences of Teen Childbearing Reconsidered.” Quarterly Journal of Economics. 107: 1187-1214.

Gold, SD, DM Smith, and SB Lawton (1995) Public School Finance Programs of the United States and Canada 1993-94, Volumes I and II. American Education Finance Association, Center for the Study of the States, the Nelson A. Rockefeller Institute of Government and the State University of New York.

Goldhaber, Dan D. (1996) "Public and Private High Schools: Is School Choice an Answer to the Productivity Problem?” Economics of Education Review. 15(2): 93-109.

Greene, Jay P., Joseph Giammo, and Nicole Mellow (1999) "The Effect of Private Education on Political Participation, Social Capital and Tolerance: An Examination of the Latino National Political Survey." Georgetown Public Policy Review. 5(1): 53-71.

Grogger, Jeffrey and Derek Neal (2000) "Further Evidence on the Effects of Catholic Secondary Schooling." Brookings-Wharton Papers on Urban Affairs, 2000. William G. Gale and Janet Rothenberg Pack (Editors). Washington, DC: Brookings. pp. 151-201.

Gruber, Jonathan (2000) "Risky Behavior Among Youths: An Economic Analysis." NBER Working Paper Number W7781.

Gruber, Jonathan and Botond Koszegi (2000) "Is Addiction 'Rational'? Theory and Evidence." NBER Working Paper Number W7507.

Hausman, Jerry A. (1983) "Specification and Estimation of Simultaneous Equation Models." In Handbook of Econometrics, Volume 1. Zvi Griliches and Michael Intriligator (Eds.)

Amsterdam: North Holland. pp. 391-448.

Hotz, V. Joseph, Susan Williams McElroy and Seth G. Sanders (1999) “Teenage Childbearing and Its Life Cycle Consequences: Exploiting a Natural Experiment." NBER Working Paper W7397.

Hoxby, Caroline and M. Daniele Paserman. 1998. "Overidentification Tests with Grouped Data." NBER Technical Working Paper 223.

Imbens, Guido W. and Joshua D. Angrist (1994) "Identification and Estimation of Local Average Treatment Effects.” Econometrica. 62(2): 467-475.

Katz, Lawrence F., Jeffrey R. Kling, and Jeffrey B. Liebman (2000) "Moving to Opportunity in Boston: Early Impacts of a Housing Mobility Program.” Princeton University Industrial Relations Section Working Paper 441. 
Klein, Malcolm W. (1995) "Street Gang Cycles.” In Crime. James Q. Wilson and Joan Petersilia (Eds.) San Francisco, CA: Institute for Contemporary Studies Press. pp. 217-236.

Klepinger, Daniel, Shelly Lundberg, and Robert Plotnick (1999) "How Does Adolescent Fertility Affect the Human Capital and Wages of Young Women?" Journal of Human Resources. 34(3): 421-448.

Leuchtenberger, C (1983) "Effects of Marhuana (Cannabis) Smoke On Cellular Biochemistry of In Vitro Test Systems." In K.O. Fehr and H. Kalant (Eds.) Cannabis and Health Hazards. Toronto: Addiction Research Foundation.

Levitt, Steven D. and Jack Porter (1999) "Estimating the Effect of Alcohol on Driver Risk Using Only Fatal Accident Statistics.” NBER Working Paper Number W6944.

Levy, Frank and Richard J. Murnane (1992) "U.S. Earnings Levels and Earnings Inequality: A Review of Recent Trends and Proposed Explanations." Journal of Economic Literature. 30: $1333-1381$.

Ludwig, Jens. (1997) "Educational Achievement in Public, Private, and Catholic Schools: New Evidence on What We Know (and Don't Know)." Working Paper, Georgetown University.

Ludwig, Jens, Greg J. Duncan, and Paul Hirschfield (Forthcoming) "Urban Poverty and Juvenile Crime: Evidence from a Randomized Housing-Mobility Experiment." Quarterly Journal of Economics.

Manning, Willard G., Emmett B. Keeler, Joseph P. Newhouse, Elizabeth M. Sloss, and Jeffrey Wasserman (1991) The Costs of Poor Health Habits. Cambridge, MA: Harvard University Press.

Markowitz, Sara and Michael Grossman (1996) "Alcohol Regulation and Violence Towards Children.” Contemporary Economic Policy. 16(3): 309-320.

Moore, Michael J. and Philip J. Cook (1995) "Habit and Heterogeneity in the Youthful Demand for Alcohol.” NBER Working Paper Number W5152.

Murnane, Richard J., Stuart Newstead, and Randall Olsen (1985) "Comparing Public and Private Schools: The Puzzling Role of Selectivity Bias." Journal of Business and Economic Statistics. 3: 23-35.

Murnane, Richard J., John B. Willet, and Frank Levy (1995) "The Growing Importance of Cognitive Skills in Wage Determination.” Review of Economics and Statistics. 77(2): 251-266.

Murnane, Richard J., John B. Willet, Yves Duhaldeborde, and John H. Tyler (2000) “How 
Important Are the Cognitive Skills of Teenagers in Predicting Subsequent Earnings?" Journal of Policy Analysis and Management. 19(4): 547-568.

National Institute on Drug Abuse, Monitoring the Future Study 1975-1996. (Downloaded from the NIDA world wide web site, at ww.nida.nih.gov/NIDACapsules/NCMTFuture.html\#Lifetime)

Neal, Derek. (1997) "The Effect of Catholic Secondary Schooling on Educational Attainment." Journal of Labor Economics. 15(1): 98-123.

Newcombe, MD, and P Bentler (1988) Consequences of Adolescent Drug Use: Impact on the Lives of Young Adults. Newbury Park, CA: Sage Publications.

Newey, Whitney (1985) “Generalized Method of Moments Specification Testing." Journal of Econometrics. 29: 229-256.

Pacula, Rosalie Liccardo (1998) "Adolescent Alcohol and Marijuana Consumption: Is There Really a Gateway Effect?” NBER Working Paper 6348.

Pope, HG, and Yurgelun-Todd, D (1996) "The residual cognitive effects of heavy marijuana use in college students." Journal of the American Medical Association. 275: 521-527.

Rouse, Cecilia E. (1998) "Private School Vouchers and Student Achievement: An Evaluation of the Milwaukee Parental Choice Program." Quarterly Journal of Economics. 113(2): 553-602.

Shore-Shepard, Lara (1996) “The Precision of Instrumental Variables Estimates With Grouped Data.” Working Paper 374, Industrial Relations Section, Princeton University.

Small, Kenneth A. and Clifford Winston (1999) "The Demand for Transportation: Models and Applications." In Essays in Transportation Economics and Policy: A Handbook in Honor of John R. Meyer. Jose A. Gomez-Ibanez, William B. Tye, and Clifford Winston (Eds.)

Washington, DC: Brookings Institution. pp. 11-56.

Staiger, Douglas and James H. Stock (1997) "Instrumental Variables Regression With Weak Instruments." Econometrica. 65(3): 557-586.

Tashkin, DP, AH Coulson, VA Clark, M Simmons, LB Borque, S Duann, GH Spivey, and H Gong (1987) "Respiratory symptoms and lung function in habitual heavy smokers of marijuana alone, smoker of marijuana and tobacco, smokers of tobacco alone, and nonsmokers." American Review of Respiratory Diseases. 135: 209-216.

Turner, Charles F., Leighton Ku, Freya L. Sonenstein, and Joseph H. Pleck (1998) "Adolescent Sexual Behavior, Drug Use and Violence: New Survey Technology Detects Elevated Prevalence." Science. 280(8): 867-873. 
U.S. Bureau of the Census (1994) Statistical Abstracts of the United States: 1994 (114 ${ }^{\text {th }}$ Edition). Washington, DC: Government Printing Office.

U.S. Department of Education (1994) NELS:88 Second Follow-Up User's Guide, Student Sample. Washington, DC: Government Printing Office.

U.S. General Accounting Office (1995) School Finance: Trends in U.S. Education Spending. Washington, D.C.: Government Printing Office.

Wolf, Patrick J., Jay P. Greene, Brett Kleitz, and Kristina Thalhammer (2000) "Political Tolerance and America's Schools.” Working Paper, Georgetown Public Policy Institute, Georgetown University. 
Table 1

Selected Descriptive Statistics for NELS Analytic Sample

\begin{tabular}{|c|c|c|}
\hline & $\begin{array}{l}\text { Base year } \\
(1988)\end{array}$ & $\begin{array}{l}\text { First follow-up } \\
\text { (1990) }\end{array}$ \\
\hline $\begin{array}{l}\text { Male } \\
\text { Age as of March, } 1992 \\
\quad \geq 20 \\
\quad 19 \\
18 \\
\quad 17 \\
\leq 16 \\
\text { Race / Ethnicity } \\
\text { African-American } \\
\text { Hispanic } \\
\text { Asian } \\
\text { American Indian }\end{array}$ & $\begin{array}{l}0.503(0.006) \\
0.008(0.001) \\
0.073(0.004) \\
0.467(0.007) \\
0.447(0.007) \\
0.005(0.001) \\
\\
0.129(0.009) \\
0.102(0.008) \\
0.036(0.003) \\
0.040(0.003)\end{array}$ & \\
\hline $\begin{array}{l}\text { Family is Catholic } \\
\text { Mother's education } \\
\text { Less than HS } \\
\text { HS } \\
\text { Some college } \\
\text { College } \\
\text { More than college } \\
\text { Family Income } \\
\text { \$0-\$15K } \\
\text { \$15K-\$25K } \\
\text { \$25K-\$35K } \\
\text { \$35K-\$50K } \\
\text { \$50K-\$75K } \\
\$ 75 \mathrm{~K} \text { plus }\end{array}$ & $\begin{array}{l}0.257(0.010) \\
0.178(0.007) \\
0.250(0.006) \\
0.409(0.007) \\
0.111(0.005) \\
0.060(0.004) \\
0.202(0.008) \\
0.174(0.005) \\
0.188(0.005) \\
0.208(0.006) \\
0.153(0.006) \\
0.075(0.005)\end{array}$ & \\
\hline $\begin{array}{l}\text { School Sector } \\
\text { Public } \\
\text { Religious private } \\
\text { Non-religious private } \\
\text { Instruments } \\
\text { Places Rated Almanac MSA data available for student } \\
\text { Rail cars per } 1000 \text { population }\end{array}$ & & $\begin{array}{l}0.904(0.009) \\
0.078(0.008) \\
0.019(0.003) \\
0.623(0.015) \\
0.044(0.004)\end{array}$ \\
\hline
\end{tabular}

NOTES TO TABLE 1:

Descriptive statistics for NELS respondents, calculated using NELS sampling weights. 
Table 2

Descriptive Statistics for Delinquency by School Sector

\begin{tabular}{|c|c|c|c|}
\hline & Total & Public School in 1990 & $\begin{array}{l}\text { Religious Private School in } \\
1990\end{array}$ \\
\hline \multicolumn{4}{|l|}{ Full sample } \\
\hline Had sex before 92 & $0.745(0.008)$ & $0.756(0.007)$ & $0.595(0.033)$ \\
\hline Fecundity before 92 & $0.093(0.005)$ & $0.092(0.005)$ & $0.014(0.005)$ \\
\hline Arrested last term & $0.043(0.003)$ & $0.045(0.003)$ & $0.018(0.004)$ \\
\hline In gang & $0.035(0.003)$ & $0.034(0.003)$ & $0.036(0.010)$ \\
\hline Smokes & $0.258(0.007)$ & $0.255(0.007)$ & $0.224(0.023)$ \\
\hline Drank in last year & $0.766(0.007)$ & $0.769(0.007)$ & $0.759(0.025)$ \\
\hline $\begin{array}{l}\text { Smoked marijuana } \\
\text { last year }\end{array}$ & $0.196(0.006)$ & $0.195(0.007)$ & $0.191(0.019)$ \\
\hline Used cocaine last year & $0.026(0.002)$ & $0.027(0.002)$ & $0.019(0.006)$ \\
\hline Sample (N) & 17,022 & 15,604 & 1,418 \\
\hline \multicolumn{4}{|l|}{$\overline{\text { MSA sample }}$} \\
\hline Had sex before 92 & $0.714(0.011)$ & $0.733(0.008)$ & $0.572(0.039)$ \\
\hline Fecundity before 92 & $0.060(0.004)$ & $0.066(0.004)$ & $0.010(0.003)$ \\
\hline Arrested last term & $0.042(0.003)$ & $0.044(0.004)$ & $0.021(0.005)$ \\
\hline In gang & $0.033(0.003)$ & $0.032(0.003)$ & $0.042(0.012)$ \\
\hline Smokes & $0.227(0.007)$ & $0.228(0.007)$ & $0.221(0.024)$ \\
\hline Drank in last year & $0.776(0.007)$ & $0.776(0.007)$ & $0.776(0.023$ \\
\hline $\begin{array}{l}\text { Smoked marijuana } \\
\text { last year }\end{array}$ & $0.204(0.008)$ & $0.205(0.008)$ & $0.201(0.023)$ \\
\hline Used cocaine last year & $0.027(0.002)$ & $0.027(0.002)$ & $0.022(0.008)$ \\
\hline Sample $(\mathrm{N})$ & 10,513 & 9,346 & 1,167 \\
\hline
\end{tabular}

\section{NOTES TO TABLE 2:}

Standard errors presented in parentheses, adjusted for the clustering of NELS students within schools. Estimates are calculated using the NELS sampling weights, with the sample restricted to students enrolled in public or religious private schools in 1990. Sample size refers to the number of teens for whom we have response information for the drug use and arrest variables; the number of cases for which we have valid responses to the sexual behavior items (taken from the third follow-up survey) are typically around 60 percent as large.

Table 3 
Single-Equation Estimates

for the Effects of Religious Private Schooling on Non-Market Adolescent Outcomes

\begin{tabular}{|l|ll|ll|}
\hline & $\begin{array}{l}\text { Unweighted } \\
\text { OLS }\end{array}$ & Probit $(\mathrm{dp} / \mathrm{dx})$ & $\begin{array}{l}\text { Weighted } \\
\text { OLS }\end{array}$ & Probit $(\mathrm{dp} / \mathrm{dx})$ \\
\hline $\begin{array}{l}\text { Had sex before } \\
92\end{array}$ & $-.066(.023)^{*}$ & $-.075(.026)^{* *}$ & $-.096(.026)^{* *}$ & $-.114(.031)^{* *}$ \\
\hline $\begin{array}{l}\text { Fecundity } \\
\text { before } 92\end{array}$ & $-.005(.005)$ & $-.009(.004)^{*}$ & $-.018(.007)^{* *}$ & $-.013(.003)^{* *}$ \\
\hline $\begin{array}{l}\text { Arrested last } \\
\text { term }\end{array}$ & $-.009(.006)$ & $-.005(.005)$ & $-.015(.007)^{* *}$ & $-.009(.004)^{*}$ \\
\hline In gang & $.007(.006)$ & $.008(.006)$ & $.013(.012)$ & $.012(.009)$ \\
\hline Smokes & $.022(.017)$ & $.025(.019)$ & $.019(.022)$ & $.021(.025)$ \\
\hline $\begin{array}{l}\text { Drank in last } \\
\text { year }\end{array}$ & $.013(.017)$ & $.014(.018)$ & $-.037(.022)^{*}$ & $-.038(.023)^{*}$ \\
\hline $\begin{array}{l}\text { Smoked } \\
\text { marijuana } \\
\text { last year }\end{array}$ & $.022(.017)$ & $.015(.017)$ & $.005(.020)$ & $.003(.020)$ \\
\hline $\begin{array}{l}\text { Used cocaine } \\
\text { last year }\end{array}$ & $.001(.006)$ & $.001(.005)$ & $.005(.008)$ & $.002(.005)$ \\
\hline
\end{tabular}

\section{NOTES TO TABLE 3:}

NELS sample is restricted to those students who participated in each wave of the survey between 1988 and 1992, lived in 1990 within one of the MSAs covered by the Places Rated Almanac, and attend either Catholic or public schools. Standard errors presented in parentheses; estimates are adjusted for clustering of students within schools in the single-equation estimates, and for the clustering of students within MSA's for the IV estimates. Regression models also include controls for student gender, race, age, maternal education, paternal education interacted with whether father or adult male within the home, number of siblings, family income, urbanicity, region, whether foreign language is spoken within the home, religion, and $8^{\text {th }}$ grade outcomes (including standardized test scores in reading, math, history / social studies and science, smoking, problem behaviors in school as reflected by having been sent to the office, fighting, number of classes skipped, and sexual activity). $* *=$ Statistically significant at the 5 percent level. $*=$ Statistically significant at the 10 percent level. 
Table 4

Selected First-Stage Results for Instrumental Variables Estimates

\begin{tabular}{|l|l|}
\hline & $\begin{array}{l}\text { Dependent Variable = Religious private school attendance } \\
\text { in } 1990 \\
\text { Beta }(\mathrm{se})\end{array}$ \\
\hline Railcars per 1,000 capita & $-56.3(122.4)$ \\
Railcars $\times$ Mother more than college & $-249.6(113.2)^{* *}$ \\
Railcars $\times$ Mother college education & $-98.4(84.7)$ \\
Railcars $\times$ Mother some college & $141.5(106.05)$ \\
Railcars $\times$ Mother HS education & $14.6(113.5)$ \\
Railcars $\times$ Mother education missing & $797.9(120.5)^{* *}$ \\
& \\
Railcars $\times$ Income \$75K plus & $-189.2(139.0)$ \\
Railcars $\times$ Income \$50K-\$75K & $-63.8(86.5)$ \\
Railcars $\times$ Income \$35K-\$50K & $3.4(84.8)$ \\
Railcars $\times$ Income \$25K-\$35K & $195.3(140.2)$ \\
Railcars $\times$ Income \$15K-\$25K & $121.1(59.6)^{* *}$ \\
Railcars $\times$ Income missing & $155.2(104.2)$ \\
\hline N & 7,300 \\
R-squared & 0.173 \\
Partial R-squared on instruments & 0.012 \\
F-test for significance of instruments & $12.75^{* *}$ \\
\hline
\end{tabular}

\section{NOTES TO TABLE 4:}

Table presents first-stage results for 2SLS model using an indicator for sexually active by 1992 as the second-stage dependent variable of interest. Standard errors are in parentheses, adjusted for the clustering of NELS students at the MSA level. Analytic sample restricted to students who participated in the NELS survey between 1988 and 1992, and in 1990 were enrolled in either a Catholic or public school and lived within a MSA covered by the Places Rated Almanac (see text). Other variables included in the regression model (see Appendix Table 1) include student sex, age and race, number of siblings, mother's education, father's education interacted with whether father or adult male guardian in the home, family income, urbanicity, region, and $8^{\text {th }}$ grade standardized test scores and behavioral variables. $*=$ Statistically significant at the 10 percent level. $* *=$ Statistically significant at the 5 percent level. 
Table 5

Instrumental Variables Estimates

for the Effects of Religious Private Schooling on Non-Market Adolescent Outcomes

\begin{tabular}{|l|l|l|l|l|l|}
\hline & $\begin{array}{l}\text { 2SLS coefficient } \\
\text { for religious } \\
\text { private schooling } \\
(\mathrm{se})\end{array}$ & $\begin{array}{l}\text { GMM over- } \\
\text { identification } \\
\text { test (p-value) }\end{array}$ & $\begin{array}{l}1^{\text {st }} \text { stage F- } \\
\text { statistic for } \\
\text { instruments } \\
(\mathrm{p} \text {-value })\end{array}$ & $\begin{array}{l}1^{\text {st }} \text { stage } \\
\text { partial- } \\
\text { for } \\
\text { instruments }\end{array}$ & $\mathrm{N}$ \\
\hline Had sex before 92 & $-.244(.083)^{* *}$ & $(0.89)$ & $\begin{array}{l}12.75 \\
(<.001)\end{array}$ & 0.012 & 7,300 \\
\hline $\begin{array}{l}\text { Fecundity before } \\
92\end{array}$ & $-.073(.033)^{* *}$ & $(0.52)$ & $\begin{array}{l}11.29 \\
(<.001)\end{array}$ & 0.012 & 7,978 \\
\hline Arrested last term & $-.115(.035)^{* *}$ & $(0.48)$ & $\begin{array}{l}16.23 \\
(<.001)\end{array}$ & 0.011 & 9,610 \\
\hline In gang & $-.019(.028)$ & $(0.52)$ & $\begin{array}{l}13.56 \\
(<.001)\end{array}$ & 0.013 & 8,634 \\
\hline Smokes & $-.032(.068)$ & $(0.48)$ & $\begin{array}{l}15.24 \\
(<.001)\end{array}$ & 0.012 & 9,198 \\
\hline Drank in last year & $.028(.063)$ & $(0.30)$ & $\begin{array}{l}17.68 \\
(<.001)\end{array}$ & 0.012 & 8,590 \\
\hline $\begin{array}{l}\text { Smoked marijuana } \\
\text { last year }\end{array}$ & $.028(.078)$ & $(0.46)$ & $\begin{array}{l}18.57 \\
(<.001)\end{array}$ & 0.013 & 8,153 \\
\hline $\begin{array}{l}\text { Used cocaine last } \\
\text { year }\end{array}$ & $-.075(.026)^{* *}$ & $(0.31)$ & $\begin{array}{l}18.40 \\
(<.001)\end{array}$ & 0.013 & 8,140 \\
\hline
\end{tabular}

NOTES TO TABLE 5:

NELS sample is restricted to those students who participated in each wave of the survey between 1988 and 1992, lived in 1990 within one of the MSAs covered by the Places Rated Almanac, and attend either Catholic or public schools. Standard errors presented in parentheses; estimates are adjusted for clustering of students within schools in the single-equation estimates, and for the clustering of students within MSA's for the IV estimates. Regression models also include controls for student gender, race, age, maternal education, paternal education interacted with whether father or adult male within the home, number of siblings, family income, urbanicity, region, whether foreign language is spoken within the home, religion, and $8^{\text {th }}$ grade test scores and behavioral variables. Instrumental variables are the number of railcars per 1,000 MSA residents, as well as interaction terms between railcars per capita dichotomous indicators for maternal education and family income. $* *=$ Statistically significant at the 5 percent level. $*=$ Statistically significant at the 10 percent level. 
Table 6

Sensitivity Analyses for Instrumental Variables Estimates

\begin{tabular}{|l|l|l|l|l|l|l|}
\hline & Weighted & $\begin{array}{l}\text { Weighted (trim } \\
\text { top and bottom } \\
\text { 5 of weight } \\
\text { values) }\end{array}$ & $\begin{array}{l}\text { With peer } \\
\text { variables } \\
\text { included }\end{array}$ & $\begin{array}{l}\text { With parent } \\
\text { school } \\
\text { involvement } \\
\text { included }\end{array}$ & $\begin{array}{l}\text { Include MSA } \\
\text { population as a } \\
\text { control variable }\end{array}$ & $\begin{array}{l}\text { Delete } \\
\text { "misreporters" }\end{array}$ \\
\hline Had sex before 92 & $-.440(.149)^{* *}$ & $-.323(.133)^{* *}$ & $-.283(.086)^{* *}$ & $-.250(.086)^{* *}$ & $-.249(.086)^{* *}$ & $-.201(.088)^{* *}$ \\
\hline Fecundity before 92 & $.011(.096)$ & $-.015(.053)$ & $-.061(.034)^{*}$ & $-.054(.033)$ & $-.042(.034)$ & $-.091(.037)^{* *}$ \\
\hline Arrested last term & $-.232(.073)^{* *}$ & $-.223(.062)^{* *}$ & $-.127(.034)^{* *}$ & $-.124(.034)^{* *}$ & $-.109(.033)^{* *}$ & $-.099(.038)^{* *}$ \\
\hline In gang & $-.137(.083)$ & $-.077(.053)$ & $-.031(.031)$ & $-.030(.028)$ & $-.054(.027)^{*}$ & $-.010(.029)$ \\
\hline Smokes & $-.036(.094)$ & $-.022(.087)$ & $-.043(.073)$ & $-.016(.069)$ & $-.049(.079)$ & $.007(.069)$ \\
\hline Drank in last year & $-.090(.163)$ & $-.052(.102)$ & $.012(.064)$ & $.037(.067)$ & $.031(.059)$ & $.009(.068)$ \\
\hline $\begin{array}{l}\text { Smoked marijuana } \\
\text { last year }\end{array}$ & $.240(.097)^{* *}$ & $.104(.091)$ & $.021(.075)$ & $.063(.080)$ & $.088(.073)$ & $.066(.084)$ \\
\hline $\begin{array}{l}\text { Used cocaine last } \\
\text { year }\end{array}$ & $-.088(.067)$ & $-.098(.055)^{*}$ & $-.070(.026)^{* *}$ & $-.073(.027)^{* *}$ & $-.043(.034)$ & $-.073(.028)^{* *}$ \\
\hline
\end{tabular}

\section{NOTES TO TABLE 6:}

NELS sample is restricted to those students who participated in each wave of the survey between 1988 and 1992 , lived in 1990 within one of the MSAs covered by the Places Rated Almanac, and attend either Catholic or public schools. Standard errors presented in parentheses; estimates are adjusted for clustering of students within schools in the single-equation estimates, and for the clustering of students within MSA's for the IV estimates. Regression models also include controls for student gender, race, age, maternal education, paternal education interacted with whether father or adult male within the home, number of siblings, family income, urbanicity, region, whether foreign language is spoken within the home, religion, and $8^{\text {th }}$ grade test scores and behavioral variables. Instrumental variables are the number of railcars per 1,000 MSA residents, as well as interaction terms between railcars per capita dichotomous indicators for maternal education and family income. $* *=$ Statistically significant at the 5 percent level. $*=$ Statistically significant at the 10 percent level. 
Table 7

Sub-Group Analyses for Instrumental Variables Estimates

\begin{tabular}{|l|l|l|l|l|l|l|}
\hline & Males & Females & Urban & Suburban & $\begin{array}{l}\text { Students in 1- } \\
\text { parent } \\
\text { households }\end{array}$ & $\begin{array}{l}\text { Students in 2- } \\
\text { parent } \\
\text { households }\end{array}$ \\
\hline Had sex before 92 & $-.081(.114)$ & $-.289(.101)^{* *}$ & $-.047(.215)$ & $-.248(.085)^{* *}$ & $-.057(.094)$ & $-.310(.089)^{* *}$ \\
\hline Fecundity before 92 & $-.038(.034)$ & $-.097(.056)^{*}$ & $.248(.077)^{* *}$ & $-.133(.043)^{* *}$ & $.002(.098)$ & $-.049(.034)$ \\
\hline Arrested last term & $-.207(.056)^{* *}$ & $-.002(.024)$ & $.031(.094)$ & $-.156(.038)^{* *}$ & $.004(.053)$ & $-.142(.037)^{* *}$ \\
\hline In gang & $.089(.054)$ & $-.024(.025)$ & $.079(.108)$ & $-.014(.036)$ & $.051(.064)$ & $-.036(.031)$ \\
\hline Smokes & $-.191(.085)^{* *}$ & $-.021(.081)$ & $.166(.175)$ & $-.052(.079)$ & $.007(.153)$ & $-.065(.070)$ \\
\hline Drank in last year & $.012(.090)$ & $.017(.080)$ & $.199(.127)$ & $-.159(.066)^{* *}$ & $.098(.178)$ & $.004(.072)$ \\
\hline $\begin{array}{l}\text { Smoked marijuana } \\
\text { last year }\end{array}$ & $-.011(.124)$ & $.035(.064)$ & $.241(.219)$ & $-.032(.095)$ & $.191(.203)$ & $-.003(.090)$ \\
\hline $\begin{array}{l}\text { Used cocaine last } \\
\text { year }\end{array}$ & $-.115(.044)^{* *}$ & $-.028(.023)$ & $.015(.058)$ & $-.063(.035)^{*}$ & $-.093(.068)$ & $-.065(.034)^{*}$ \\
\hline
\end{tabular}

\section{NOTES TO TABLE 7:}

NELS sample is restricted to those students who participated in each wave of the survey between 1988 and 1992, lived in 1990 within one of the MSAs covered by the Places Rated Almanac, and attend either Catholic or public schools. Standard errors presented in parentheses; estimates are adjusted for clustering of students within schools in the single-equation estimates, and for the clustering of students within MSA's for the IV estimates. Regression models also include controls for student gender, race, age, maternal education, paternal education interacted with whether father or adult male within the home, number of siblings, family income, urbanicity, region, whether foreign language is spoken within the home, religion, and $8^{\text {th }}$ grade test scores and behavioral variables. Instrumental variables are the number of railcars per 1,000 MSA residents, as well as interaction terms between railcars per capita dichotomous indicators for maternal education and family income. $* *=$ Statistically significant at the 5 percent level. $*=$ Statistically significant at the 10 percent level. 
Appendix Table 1

Selected First-Stage Results for Instrumental Variables Estimates

\begin{tabular}{|c|c|}
\hline Explanatory Variable: & $\begin{array}{l}\text { Dependent Variable }=\text { Religious private school attendance in } \\
1990 \\
\text { Beta (se) }\end{array}$ \\
\hline $\begin{array}{l}\text { Male } \\
\text { Age } 20 \text { or older } \\
\text { Age } 19 \\
\text { Age } 18 \\
\text { Age } 16 \text { or under }\end{array}$ & $\begin{array}{l}.018(.012) \\
-.015(.032) \\
-.032(.014)^{* *} \\
-.023(.009)^{* *} \\
-.043(.046)\end{array}$ \\
\hline $\begin{array}{l}\text { Asian } \\
\text { Hispanic } \\
\text { Black } \\
\text { American Indian } \\
\text { Language other than English spoken in } \\
\text { home }\end{array}$ & $\begin{array}{l}-.058(.022)^{* *} \\
-.082(.021)^{* *} \\
-.016(.020) \\
-.032(.018)^{*} \\
-.012(.013)\end{array}$ \\
\hline $\begin{array}{l}\text { Number of siblings } \\
1 \\
2 \\
3 \\
4 \\
5 \\
6+\end{array}$ & $\begin{array}{l}-.039(.018)^{* *} \\
-.046(.019)^{* *} \\
-.031(.020) \\
-.009(.022) \\
-.039(.020)^{*} \\
-.033(.022)\end{array}$ \\
\hline $\begin{array}{l}\text { Urban } \\
\text { Suburban } \\
\text { Northeast } \\
\text { Northcentral } \\
\text { South }\end{array}$ & $\begin{array}{l}.154(.029)^{* *} \\
.044(.016)^{* *} \\
-.030(.031) \\
-.009(.034) \\
-.034(.032)\end{array}$ \\
\hline $\begin{array}{l}\text { Mother's education } \\
\text { HS } \\
\text { Some college } \\
\text { College } \\
\text { College or more } \\
\text { Missing } \\
\text { Family Income } \\
\$ 15 \mathrm{~K}-\$ 25 \mathrm{~K} \\
\$ 25 \mathrm{~K}-\$ 35 \mathrm{~K} \\
\$ 35 \mathrm{~K}-\$ 50 \mathrm{~K} \\
\$ 50 \mathrm{~K}-\$ 75 \mathrm{~K} \\
\$ 75 \mathrm{~K} \text { plus } \\
\text { Income missing }\end{array}$ & $\begin{array}{l}.007(.009) \\
.018(.010)^{*} \\
.043(.019)^{* *} \\
.059(.025) \\
-.00001(.025) \\
.009(.011) \\
.013(.012) \\
.048(.015)^{* *} \\
.051(.018)^{* *} \\
.134(.036)^{* *} \\
.082(.025)^{* *}\end{array}$ \\
\hline
\end{tabular}




\begin{tabular}{|c|c|}
\hline $\begin{array}{l}\text { Religion } \\
\text { Baptist } \\
\text { Protestant } \\
\text { Mormon } \\
\text { Jewish } \\
\text { Moslem } \\
\text { Eastern-Orthodox } \\
\text { No religious affiliation (atheist) }\end{array}$ & $\begin{array}{l}-.180(.030)^{* *} \\
-.164(.030)^{* *} \\
-.261(.033)^{* *} \\
-.118(.045)^{* *} \\
-.169(.041)^{* *} \\
-.200(.038)^{* *} \\
-.176(.025)^{* *}\end{array}$ \\
\hline $\begin{array}{l}\text { Father not in home, HS dropout } \\
\text { Father in home, HS graduate } \\
\text { Father not in home, HS graduate } \\
\text { Father in home, some college } \\
\text { Father not in home, some college } \\
\text { Father in home, college graduate } \\
\text { Father not in home, college graduate } \\
\text { Father in home, more than college } \\
\text { Father not in home, more than college } \\
\text { Father in home, education missing } \\
\text { Father not in home, education missing } \\
\text { (Father in home, HS dropout is omitted) }\end{array}$ & $\begin{array}{l}-.021(.016) \\
.016(.014) \\
.009(.030) \\
.007(.011) \\
.028(.036) \\
.033(.018)^{*} \\
.088(.022)^{* *} \\
.028(.018) \\
.167(.101) \\
.061(.018)^{* *} \\
.016(.010)\end{array}$ \\
\hline $\begin{array}{l}8^{\text {th }} \text { grade reading scores } \\
8^{\text {th }} \text { grade math scores } \\
8^{\text {th }} \text { grade science scores } \\
8^{\text {th }} \text { grade history / social studies scores }\end{array}$ & $\begin{array}{l}.002(.001)^{* *} \\
-.0005(.001) \\
-.003(.002)^{*} \\
.003(.002)^{* *}\end{array}$ \\
\hline $\begin{array}{l}1988 \text { behavioral variables } \\
\text { Smoke }\end{array}$ & $.021(.014)$ \\
\hline $\begin{array}{l}\text { Sent to office for misbehavior } 1 \text { or } 2 \text { times } \\
\text { Sent to office for misbehavior } 2+\text { times }\end{array}$ & $\begin{array}{l}-.036(.012)^{* *} \\
-.076(.017)^{* *}\end{array}$ \\
\hline $\begin{array}{l}\text { Parents warned about behavior } 1-2 \text { times } \\
\text { Parents warned about behavior } 2+\text { times }\end{array}$ & $\begin{array}{l}.028(.013)^{* *} \\
.033(.021)\end{array}$ \\
\hline Had sex & $-.022(.014)$ \\
\hline $\begin{array}{l}\text { Got into fight with other student } 1-2 \text { times } \\
\text { Got into fight with other student } 2+\text { times }\end{array}$ & $\begin{array}{l}.032(.014)^{* *} \\
.032(.019)^{*}\end{array}$ \\
\hline $\begin{array}{l}\text { Skip class less than once a week } \\
\text { Skip class at least once a week } \\
\text { Skip class daily }\end{array}$ & $\begin{array}{l}-.047(.016)^{* *} \\
-.027(.029) \\
-.061(.041)\end{array}$ \\
\hline $\begin{array}{l}\text { Missed 1-2 days of school last } 4 \text { weeks } \\
\text { Missed 3-4 days of school last } 4 \text { weeks } \\
\text { Missed 5-10 days of school last } 4 \text { weeks } \\
\text { Missed } 10 \text { or more days of school last } 4 \text { wks }\end{array}$ & $\begin{array}{l}-.018(.008)^{* *} \\
-.052(.012)^{* *} \\
-.001(.014) \\
-.004(.024)\end{array}$ \\
\hline
\end{tabular}




\begin{tabular}{|l|c|}
\hline Instrumental Variables & \\
Railcars per 1,000 capita & $-56.3(122.4)$ \\
& $-249.6(113.2)^{* *}$ \\
Railcars $\times$ Mother more than college & $-98.4(84.7)$ \\
Railcars $\times$ Mother college education & $141.5(106.1)$ \\
Railcars $\times$ Mother some college & $14.6(113.5)$ \\
Railcars $\times$ Mother HS education & $797.9(120.5)^{* *}$ \\
Railcars $\times$ Mother education missing & $-189.2(139.1)$ \\
& $-63.8(86.5)$ \\
Railcars $\times$ Income \$75K plus & $3.4(84.8)$ \\
Railcars $\times$ Income \$50K-\$75K & $195.3(140.2)$ \\
Railcars $\times$ Income \$35K-\$50K & $121.1(59.6)^{* *}$ \\
Railcars $\times$ Income \$25K-\$35K & $155.2(104.2)$ \\
Railcars $\times$ Income \$15K-\$25K & $.079(.047)^{*}$ \\
Railcars $\times$ Income missing & 7,300 \\
\hline Constant & 0.173 \\
\hline N & \\
R-squared & \\
\hline
\end{tabular}

\section{NOTES TO APPENDIX TABLE 1:}

Table presents first-stage results for 2SLS model using sexual activity in 1992 as the second-stage dependent variable of interest. Standard errors are in parentheses, adjusted for the clustering of NELS students at the MSA level. Analytic sample restricted to students who participated in the NELS survey between 1988 and 1992, and in 1990 were enrolled in either a Catholic or public school and lived within a MSA covered by the Places Rated Almanac (see text). Other variables included in the regression model (results not shown) include missing-data indicators for eighth grade problem behaviors, eighth grade test scores, eighth grade sexual activity, age, race, religion, and number of siblings. $*=$ Statistically significant at the 10 percent level. $* *=$ Statistically significant at the 5 percent level. 
Appendix Table 2

Selected Second-Stage Results for Instrumental Variables Estimates

\begin{tabular}{|c|c|c|c|}
\hline Explanatory Variable: & $\begin{array}{l}\text { Dependent variable: } \\
\text { Had sex before } 1992\end{array}$ & $\begin{array}{l}\text { Dependent variable: } \\
\text { Used cocaine last year }\end{array}$ & $\begin{array}{l}\text { Dependent variable: } \\
\text { Arrested last term }\end{array}$ \\
\hline $\begin{array}{l}\text { Attend religious private school in } \\
1990 \text { (predicted value) }\end{array}$ & $-.244(.083)^{* *}$ & $-.075(.026)^{* *}$ & $-.115(.035)^{* *}$ \\
\hline $\begin{array}{l}\text { Male } \\
\text { Age } 20 \text { or older } \\
\text { Age } 19 \\
\text { Age } 18 \\
\text { Age } 16 \text { or under }\end{array}$ & $\begin{array}{l}.044(.015)^{* *} \\
-.083(.059) \\
.013(.019) \\
.027(.010)^{* *} \\
-.142(.082)^{*}\end{array}$ & $\begin{array}{l}-.003(.003) \\
-.046(.012)^{* *} \\
-.016(.009)^{*} \\
-.002(.005) \\
-.021(.007)^{* *}\end{array}$ & $\begin{array}{l}.031(.004)^{* *} \\
-.042(.024)^{*} \\
-.013(.010) \\
-.007(.005) \\
-.002(.025)\end{array}$ \\
\hline $\begin{array}{l}\text { Asian } \\
\text { Hispanic } \\
\text { Black } \\
\text { American Indian } \\
\text { Other language besides English } \\
\text { spoken in home }\end{array}$ & $\begin{array}{l}-.131(.029)^{* *} \\
.001(.022) \\
.052(.021)^{* *} \\
-.020(.025) \\
-.102(.023)^{* *}\end{array}$ & $\begin{array}{l}-.006(.008) \\
-.0004(.008) \\
-.024(.007)^{* *} \\
-.014(.009) \\
-.002(.006)\end{array}$ & $\begin{array}{l}-.026(.010)^{* *} \\
-.020(.007)^{* *} \\
-.004(.009) \\
.005(.013) \\
.008(.008)\end{array}$ \\
\hline $\begin{array}{l}\text { Number of siblings } \\
1 \\
2 \\
3 \\
4 \\
5 \\
6+\end{array}$ & $\begin{array}{l}.004(.021) \\
-.008(.024) \\
-.007(.028) \\
.005(.030) \\
.003(.028) \\
-.022(.029)\end{array}$ & $\begin{array}{l}-.009(.007) \\
-.0003(.007) \\
-.002(.008) \\
.006(.010) \\
-.009(.011) \\
-.016(.010)\end{array}$ & $\begin{array}{l}-.016(.011) \\
-.016(.011) \\
-.011(.013) \\
-.007(.010) \\
-.016(.017) \\
-.021(.013)\end{array}$ \\
\hline $\begin{array}{l}\text { Urban } \\
\text { Suburban } \\
\text { Northeast } \\
\text { Northcentral } \\
\text { South }\end{array}$ & $\begin{array}{l}.006(.028) \\
-.007(.020) \\
.013(.018) \\
.025(.021) \\
.008(.019)\end{array}$ & $\begin{array}{l}.010(.009) \\
.010(.008) \\
-.004(.008) \\
-.009(.006) \\
-.008(.006)\end{array}$ & $\begin{array}{l}.015(.010) \\
.004(.008) \\
-.006(.008) \\
.009(.008) \\
-.013(.007)^{*}\end{array}$ \\
\hline $\begin{array}{l}\text { Mother's education } \\
\text { HS } \\
\text { Some college } \\
\text { College } \\
\text { College or more } \\
\text { Missing } \\
\text { Family Income } \\
\$ 15 \mathrm{~K}-\$ 25 \mathrm{~K} \\
\$ 25 \mathrm{~K}-\$ 35 \mathrm{~K} \\
\$ 35 \mathrm{~K}-\$ 50 \mathrm{~K} \\
\$ 50 \mathrm{~K}-\$ 75 \mathrm{~K} \\
\text { \$75K plus } \\
\text { Income missing }\end{array}$ & $\begin{array}{l}-.013(.017) \\
.016(.016) \\
-.043(.022)^{*} \\
-.040(.034) \\
-.005(.026) \\
-.008(.018) \\
.040(.021)^{*} \\
.016(.022) \\
.051(.023)^{* *} \\
.082(.029)^{* *} \\
.017(.028)\end{array}$ & $\begin{array}{l}.001(.008) \\
.007(.008) \\
-.004(.007) \\
-.001(.008) \\
-.0004(.010) \\
.007(.007) \\
.007(.007) \\
.014(.007)^{*} \\
.003(.007) \\
.014(.007)^{* *} \\
.023(.011)^{* *}\end{array}$ & $\begin{array}{l}-.002(.010) \\
-.004(.009) \\
-.0002(.009) \\
-.015(.008)^{*} \\
.022(.013)^{*} \\
.010(.007) \\
.011(.007) \\
.016(.008)^{*} \\
.020(.009)^{* *} \\
.032(.010)^{* *} \\
-.0004(.010)\end{array}$ \\
\hline
\end{tabular}




\begin{tabular}{|c|c|c|c|}
\hline $\begin{array}{l}\text { Religion } \\
\text { Baptist } \\
\text { Protestant } \\
\text { Mormon } \\
\text { Jewish } \\
\text { Moslem } \\
\text { Eastern-Orthodox } \\
\text { No religious affiliation (atheist) }\end{array}$ & $\begin{array}{l}-.035(.024) \\
-.058(.020)^{* *} \\
-.236(.052)^{* *} \\
-.163(.043)^{* *} \\
-.168(.088)^{*} \\
-.118(.056)^{* *} \\
-.008(.025)\end{array}$ & $\begin{array}{l}-.014(.006)^{* *} \\
-.011(.005)^{* *} \\
-.023(.014) \\
-.013(.010) \\
-.028(.010)^{* *} \\
-.021(.012)^{*} \\
.002(.010)\end{array}$ & $\begin{array}{l}-.016(.009)^{*} \\
-.015(.008)^{*} \\
-.027(.012)^{* *} \\
-.008(.014) \\
.045(.045) \\
-.004(.018) \\
-.006(.011)\end{array}$ \\
\hline $\begin{array}{l}\text { Father not in home, HS dropout } \\
\text { Father in home, HS graduate } \\
\text { Father not in home, HS graduate } \\
\text { Father in home, some college } \\
\text { Father not in home, some college } \\
\text { Father in home, college graduate } \\
\text { Father not in home, college graduate } \\
\text { Father in home, more than college } \\
\text { Father not in home, more than college } \\
\text { Father in home, education missing } \\
\text { Father not in home, ed missing } \\
\text { (Father in home, HS dropout is } \\
\text { omitted) }\end{array}$ & $\begin{array}{l}-.053(.064) \\
.036(.017)^{* *} \\
-.016(.062) \\
-.009(.016) \\
-.031(.068) \\
-.023(.024) \\
.084(.077) \\
-.066(.026)^{* *} \\
-.246(.145)^{*} \\
-.007(.024) \\
.044(.022)^{* *}\end{array}$ & $\begin{array}{l}-.032(.009)^{* *} \\
-.015(.009)^{*} \\
-.032(.010)^{* *} \\
-.009(.008) \\
-.003(.027) \\
-.006(.009) \\
.002(.054) \\
-.022(.008)^{* *} \\
-.008(.013) \\
-.006(.010) \\
-.002(.009)\end{array}$ & $\begin{array}{l}-.00003(.028) \\
.006(.009) \\
.017(.044) \\
.003(.008) \\
-.003(.020) \\
.002(.009) \\
-.063(.014)^{* *} \\
.003(.010) \\
.067(.080) \\
.020(.011)^{*} \\
.001(.009)\end{array}$ \\
\hline $\begin{array}{l}8^{\text {th }} \text { grade reading scores } \\
8^{\text {th }} \text { grade math scores } \\
8^{\text {th }} \text { grade science scores } \\
8^{\text {th }} \text { grade history / social studies }\end{array}$ & $\begin{array}{l}-.002(.001)^{* *} \\
-.002(.001)^{* *} \\
.001(.002) \\
-.002(.002)\end{array}$ & $\begin{array}{l}-.001(.0003)^{*} \\
.0001(.0002) \\
.001(.001)^{*} \\
-.0001(.0005)\end{array}$ & $\begin{array}{l}-.0001(.0004) \\
-.0004(.0002)^{*} \\
-.0005(.0006) \\
-.0003(.0007)\end{array}$ \\
\hline \multicolumn{4}{|l|}{ Eighth grade behavioral variables } \\
\hline Smoke & $.085(.018)^{* *}$ & $.020(.014)$ & $.008(.012)$ \\
\hline Sent to office for misbehavior $1-2 \mathrm{tms}$ & $.064(.018)^{* *}$ & $.029(.008)^{* *}$ & $.010(.007)$ \\
\hline Sent to office for misbehavior $2+\mathrm{tms}$ & $.034(.018)^{*}$ & $.024(.012)^{* *}$ & $.015(.013)$ \\
\hline Parents warned about behavior 1-2 & $.047(.016)^{* *}$ & $.003(.006)$ & $.028(.008)^{* *}$ \\
\hline Parents warned about behavior $2+$ & $.035(.022)$ & $.068(.019)^{* *}$ & $.056(.017)^{* *}$ \\
\hline Had sex & $.227(.011)^{* *}$ & $.017(.009)^{*}$ & $.038(.009)^{* *}$ \\
\hline Got into fight with other student $1-2$ & $.060(.016)^{* *}$ & $.008(.007)$ & $.021(.008)^{*}$ \\
\hline Got into fight with other student $2+$ & $.037(.019)^{*}$ & $.006(.015)$ & $.026(.017)$ \\
\hline Skip class $<1$ per week & $.046(.021)^{* *}$ & $.031(.013)^{* *}$ & $.002(.010)$ \\
\hline Skip class $>=1$ per week & $.026(.035)$ & $.015(.026)$ & $-.006(.030)$ \\
\hline Skip class daily & $-.048(.062)$ & $.016(.041)$ & $.056(.050)$ \\
\hline Missed 1-2 days school last 4 weeks & $.049(.012)^{* *}$ & $.007(.004)$ & $.006(.005)$ \\
\hline Missed 3-4 days school last 4 weeks & $.044(.016)^{* *}$ & $-.001(.006)$ & $-.001(.006)$ \\
\hline Missed 5-10 days school last 4 weeks & .014 (.028) & $.003(.010)$ & $.023(.013)^{*}$ \\
\hline Missed 10 or more days last 4 weeks & $.028(.040)$ & $.018(.022)$ & $-.004(.017)$ \\
\hline Constant & $.810(.072)^{* *}$ & $.019(.019)$ & $.061(.024)^{* *}$ \\
\hline
\end{tabular}




\begin{tabular}{|l|l|l|l|}
\hline $\mathrm{N}$ & 7,300 & 8,140 & 9,610 \\
$\mathrm{R}$-squared & 0.1435 & 0.0249 & 0.0280 \\
\hline
\end{tabular}

\section{NOTES TO APPENDIX TABLE 2:}

Table presents second-stage results for 2SLS model using as instrumental variables railcars per capita, and railcars per capita interacted with indicators for mother's educational attainment and family income. Standard errors are in parentheses, adjusted for the clustering of NELS students at the MSA level. Analytic sample restricted to students who participated in the NELS survey between 1988 and 1992, and in 1990 were enrolled in either a Catholic or public school and lived within a MSA covered by the Places Rated Almanac (see text). Other variables included in the regression model (results not shown) include missing-data indicators for eighth grade problem behaviors, eighth grade test scores, eighth grade sexual activity, age, race, religion, and number of siblings. $*=$ Statistically significant at the 10 percent level. $* *=$ Statistically significant at the 5 percent level. 